\title{
THE PROFIT AND LOSS ACCOUNT IN DIFFERENT APPROACHES. ADVANTAGES AND DISADVANTAGES
}

\author{
Mariana Man ${ }^{1}$ \\ Liana Gădău ${ }^{2}$
}

ABSTRACT: The evolution, the development of increasingly complex activities emphasizes the utility, the necessity of the profit and loss account in the financial reporting by increasing the interest in the enterprise performance, especially for the dynamic information that this situation can provide

In this paper we propose to approach the profit and loss account in view of two representative referential, namely in terms of IAS 1 standard " The preparation and presentation of the financial statements" and the European Accounting Directives, aiming to emphasize the advantages, but also the limits provided by this models. This way, will see which of these models of profit and loss account respond best to users' needs.

In the second part of the paper, we present the model for the profit and loss account proposed by the economist RJ Thacker. This model shows interest in terms of efficiency of enterprise management. Even if this model has its limits, it deserves to be analysis thorough an elaborate study.

Key words: financial statements, profit and loss account, financial performance, results

JEL codes: $M 40$, M41

\section{Introduction}

The evolution, the development of increasingly complex activities emphasizes the utility, the necessity of the profit and loss account in the financial reporting by increasing the interest in the enterprise performance, especially for the dynamic information that this situation can provide. Meanwhile, there is a declining interest in the historical costs and static information. Although the balance sheet contains information on performance, it does not prevent the achievement of its forecasts.

In this paper we propose to approach the profit and loss account in view of two representative referential, namely in terms of IAS 1 standard " The preparation and presentation of the financial statements" and the European Accounting Directives, aiming to emphasize the advantages, but also the limits provided by this models. This way, will see which of these models of profit and loss account respond best to users' needs.

In the second part of the paper, we present the model for the profit and loss account proposed by the economist RJ Thacker. This model shows interest in terms of efficiency of enterprise management. Even if this model has its limits, it deserves to be analysis thorough an elaborate study.

The financial performance - a very complex notion and high informational load for users of accounting information is reflected best by the financial statements, the profit and loss account and the situation of equity variations. The last situation can be presented as a statement of

\footnotetext{
${ }^{1}$ University of Petrosani Romania, man_mariana2006@yahoo.com

${ }^{2}$ Spiru Haret University, Bucharest, lianagadau@yahoo.com
} 
comprehensive income, including beside the result of profit and loss account, the gains and losses directly recognized in equities without passing through the profit and loss account.

The information regarding the performance of an enterprise, especially its profitability, helps to assess the potential changes of economic resources that the enterprise can control in the future. In addition, they are used to anticipate the enterprise capacity to generate future cash flows with the existing resources. The same information is useful for formulating and reasoning the efficiency of the enterprise to procure new resources.

The result of the financial exercise, expressed in the profit and loss account, is commonly used as a measure for assessing the activity of an enterprise's financial performance.

The concept of "performance" is differently interpreted by the users of accounting information, depending on their interests. Thus, the managers are interested in the substantiation of decisions on overall performance, the investors are especially interested in the profitability of their investments, the employees are interested in the stability and profitability of the enterprise, and the creditors are interested in the solvency and company's ability to pay debts according to schedule. We can say that measuring the activity of an enterprise's financial performance is based on the user's objectives.

In addition, the profit and loss account provides the essential information in the forecasting of the enterprise's capability to generate future cash flows.

A question that can be made is how the information contained on this situation can help users in predicting future cash flows, knowing that this situation provides information to assess the past performance of the enterprise. The substantiation of the response is based on the following thinking, a positive past performance is not an absolute guarantee of a desired positive development, but the analysis can trace the future evolution trend of enterprise' activity, within certain margin of risk. Moreover, the profit and loss account helps users in determining the risk or the uncertainty level regarding the future cash flows.

However, the results from accounting are the consequences of applying series of postulates, principles, independence of financial exercises and connection of expenses to incomes that is why this synthesis document must be treated with a dose of prudence.

The conceptual framework of international accounting in connection with the profit and loss account defines and characterizes the elements that describe the enterprise's financial performance, namely: the incomes and the expenses.

The definition proposed by the IASB accounting framework for revenues and expenditures are very comprehensive, they refer to both incomes/expenditures incurred in the normal course of activities and to gains/losses, ups/downs of securities that can occurs during the accounting period, whether are latent or realized.

\section{The profit and loss account under the vision of the IAS 1 "The preparation and presentation of the financial statements"}

Through the revisions of IAS 1 "The preparation and presentation of the financial statements" in September 2007, entered into force in January 2009 were reviewed the requirements of presentation of the incomes and expenditures realized by an enterprise. Thus the revised IAS 1 offers to entities two versions (options) to present all the items of incomes and expenses (including those directly affected by the equity), namely:

- To be presented in one unique financial situation called "The statement of the comprehensive income";

- To be presented in two financial statements:

- The profit and loss account and

- The statement of the comprehensive income. 
The conceptual framework of IASB approves the first version of the presentation, because there are not sufficient principles, solid foundations, clear evidences to justify the separation of revenues and expenses in two financial statements.

"The statement of the comprehensive income" should be given separate headings: The profit or loss account and other elements of the comprehensive income.

The section "Other elements of the comprehensive income" comprises:

- The variation of the reserve reevaluation after the assets revaluation (falling under the incidence of IAS 16 and IAS 38);

- The gains and losses from the revaluation of the financial assets measured at fair value (falling under the incidence of IAS 39);

- The gains and losses from the evaluation of instruments used to cover the risks of cash flows (falling under the incidence of IAS 39);

- The gains and losses arising from the conversion of the financial statements of abroad operations (IAS 21) etc

From the financial analysis of the three situations listed above, the last two cases are obtained by separating the first financial statements "The statement of compressive income as a unique situation" in two distinct situations: "The profit and loss account" and "The statement of the comprehensive income", keeping the order of the headings. The idea is to distinguish a situation that shows the elements which directly contributed to the acquirement of profit or loss, called "The profit and loss account".

Moreover, "The profit and loss account" should presented different the profit or loss obtained under conditions of normal activity from the profit or loss derived from uncertain or discontinuous operations.

It is interesting to analyze the first part of "The comprehensive income as a unique situation" called profit or loss. Thus, the IAS 1 enables enterprise to decide on the structure and content of the revenues and expenditures reported in profit or loss, offering this way a minimal list of items that must be listed. The enterprises have the freedom to choose between a presentation of expenses by nature or by function, but they must be very careful in their choosing, not to distort the financial performance of the activity.

In addition, the historical factors, the specific field of activity, but also the natures of the organization influence the selection of one of the two methods of presentation.

The international standard IAS 1 does not propose a rigid structure of the profit and loss account, but encourages the exercise of professional reasoning in assessing the significance of an item of income or expense. If they are significant, the elements are presented separately, depending on the nature or importance.

The costs and revenues, analyzed by their nature, separate into operating expenses and incomes and financial expenses and incomes.

The category of operating expenses and revenues includes those incurred in: obtaining production, the sale of stocks, the provided services, other expenses and incomes such as donations, compensations, subsidies, costs and incomes from the assets adjustment in order to present their non-financial debt in the balance sheet, gains and losses from sales of tangible and intangible assets, etc.

In addition, in the financial revenues and expenditures category we can mention the interests, incomes from securities held in associated companies, expenditures and revenues from adjustments of assets and financial liabilities in order to present them into the balance sheet, gains and losses from sales of financial assets, the differences from exchange rate etc.

The operating and financial revenues and expenses are considered ordinary because they are quite common and occur during the normal activity of the enterprise. Besides these elements, there are some extraordinary events such as natural disasters, crises, nationalization etc. These events are very rare and cannot be provided and managed by the enterprise management. 
In the early form of IAS 1, the extraordinary items were presented separately in the profit and loss account. At the revision from 2003, the IAS 1 standard interdicted the presentation of such extraordinary items separately.

Through the analysis of the functions of these expenses, we can emphasize the following aspects.

The supply function - leads to the regrouping under the same heading "The cost of goods, products or services sold or supplied", or simply the cost of sales, which deducted from incomes allows the gross margin to be explicitly reveal.

The commercial function - gathers costs of sell and promotes products: salaries and other personnel costs, advertising expenses, marketing, distribution expenses.

The administrative function - includes personnel costs, certain taxes, certain fees, etc.

Next we will analyze the profit or loss of the financial exercise - under the vision of the international standard IAS 1 by two methods: the classification of expenditures both by nature and by their functions. We highlight the benefits and limitations of each method.

Table no. 1

The analysis the profit or loss of the financial exercise

\begin{tabular}{|c|c|}
\hline $\begin{array}{l}\text { The profit or loss of the exercise, with } \\
\text { the classification of the expenses by nature }\end{array}$ & $\begin{array}{l}\text { The profit or loss of the exercise, with } \\
\text { the classification of the expenses by function }\end{array}$ \\
\hline Incomes & Incomes \\
\hline Other incomes & Cost of sales \\
\hline The stocks variation & The gross margin \\
\hline Immobilized production & Other incomes \\
\hline Consumption of raw materials and consumables & Distribution costs \\
\hline Personnel expenses & Administrative expenses \\
\hline Expenses regarding the depreciation & Other expenses \\
\hline The corporal immobilizations depreciation & The financing costs \\
\hline Other expenses & The percent of profit of associated enterprise \\
\hline The financing costs & The profit before taxation \\
\hline The percent of profit of associated enterprise & Income tax expenses \\
\hline The profit before taxation & Profit or loss from continuing activities \\
\hline Income tax expenses & Profit or loss from discontinuous activities \\
\hline Profit or loss from continuing activities & The profit or loss of the exercise \\
\hline Profit or loss from discontinuous activities & \\
\hline The profit or loss of the exercise & \\
\hline
\end{tabular}

Source: International standard IAS 1

From the analysis of profit or loss of the exercise with the classification of expenses by nature, we can distinguish two positions that indicate two important indicators, namely the variation of stocks and the production assets. Through these posts are transferred the costs incorporated into the cost of inventories and fixed assets, from the profit and loss account, into the balance sheet, in order to recognize the stocks and fixed assets acquired initial from those produce by the company.

The advantages of using the method of classification of expenses by nature:

- Allows the use of profit and loss account in the calculation of intermediate balances, allows macroeconomic aggregate calculations;

- The information from the classification of expenses by nature is useful in the estimation of the future cash flows for the enterprise;

- This method is easy to apply because it does not require the allocation of operating expenses on functional classification. This model is suitable to the needs of small and medium-sized enterprises or to the large ones that do not exceed certain thresholds of indicators used in European 
boundaries: the turnover, the total assets and the number of employees. However, the Romanian specialist generalized the structure by nature to all the enterprises, regardless of their size; the structure by functions is found just in an explanatory note;

- This method provides more objective and verifiable information;

- Facilitates the cash flow projections

The disadvantages (limits) of this method:

- This model does not say anything about the performance of the management in achieving the enterprise functions.

If we analyze the scheme of profit or loss of the exercise with the classification of expenses by function, is seen that the revenue item represents the turnover. By lowering the cost of sales from the income (the turnover) is obtained the gross profit indicator, which in fact is the gross margin on cost of sales.

The cost of sales includes all costs for supplies, services provided by third parties, labor, rent and depreciation expense used in the manufacturing process of goods.

The cost of an inventory item does not include the sales and administrative expenses. So the sale cost does not include the distribution and administration expenses.

The distribution costs refer to expenses incurred in the promotion and distribution of the goods, sold by the company. (Marketing costs, staff costs used in the distribution of products, depreciation, rent space with commercial destination).

The IAS 1 standard requires companies that use the method of classification by function to present additional information about the nature of expenses, including the depreciation and personnel expenses.

The advantages of using the method of classification of expenditure by their functions:

- This presentation often provides more relevant information to users than the classification of expenses by nature, but the allocation of costs by functions can be often arbitrary and involves considerable professional reasoning;

- This model of analysis offers information on performance management regarding the business, the distribution and administration functions, so it is more relevant in the analysis of the financial performance than the other models which says almost nothing about the performance of enterprise;

- The presentation of expenses by function permits the determination of the gross margin, as a difference between the turnover and the cost of sold goods or provided services. These indicators provide important information used in the comparison of the enterprise efficiency.

The limits of the method:

- This model, even more relevant in the analysis of the financial performance, is less reliable, because the allocation of costs depends on how the enterprise management defines its function. Moreover, if managers make organizational changes and adjust the functions, then the information can not be compared over time;

- Does not allow the forecast for the future cash flows. Therefore IAS 1 requires to companies to present the additional information on the nature of expenses, including the expenses with depreciation and personnel.

If IAS 1 adopts the conception of minimum information to present in the profit and loss account, indicating the elements disclosed in this financial situation, without a standard form of the profit and loss account, the IV Directive has a different view, adopting the concept of maximum information to be presented.

Thus, the IV Directive provides standard models and diagrams that define the form and format for the profit and loss account.

The IV Directive leaves companies the opportunity to choose between the presentations of the profit and loss account as a form list or account form, both types of these schemes detail the 
operating expenses by nature or by destination. It is not allowed the modification of the presentation form of profit or loss account from a financial exercise to another.

Thus, for presenting the financial performance of the company, the IV EEC Directive recommends four schemes for profit and loss account: the form of incomes and expenditure account classified by nature and by function and the form list of expenses and incomes classified by nature.

The economic, financial, legal and cultural features of every European country have determined that each enterprise to choose the model of profit and loss account which best matches the user's information requests.

2. The profit and loss account from the IV Directive of EEC point of view by presenting it as a list form with the classification of the expenditures ad incomes both by nature, and by functions.

Next, we will analyze the profit and loss account - from the IV Directive of EEC point of view - by presenting it as a list form with the classification of the expenditures ad incomes both by nature, and by functions. The advantages offered to user by the both approaches.

The analysis the profit or loss of the financial exercise

Table no. 2

\section{The simplified form list of the profit and loss account, with the classification of the expenditures by their nature}

\section{The net turnover}

The stocks variation of the finished goods and the production in progress

The exercise production Other operating incomes Operating expenditures Adjustments of value of the tangible, intangible immobilizations and circulating assets

Other operating expenditures

Incomes from participating interest, from other investments, and loans

Receivable interest and other similar incomes

Payable interests and other similar expenditures

Profit/loss of the current activity

Extraordinaire incomes

Extraordinaire expenditures

The result of the extraordinaire activity

Income tax

The result of the financial exercise

\section{The simplified form list of the profit and loss} account, with the classification of the expenditures by their functions

The net turnover

The cost of sales

Profit/loss

The distribution cost (including the depreciations and the provisions)

General administrative expenses (including the depreciations and the provisions)

Other operating incomes

Financial incomes

Financial expenses

The income tax of the current profit of the

exercise

The net profit/loss of the current activity

Extraordinaire incomes

Extraordinaire expenditures

Source: The IV Directive of EEC

From the comparative analysis of the two schemes we noticed that the first scheme is centered on the calculation of the turnover and the exercise production and the second scheme on the calculation of the turnover and the cost of the sold goods.

The turnover represents all the incomes from the sell of goods, wares, the provided services, rents and other various activities.

The exercise production is the value of the sold production, the increasing or decreasing of the stored or immobilized production. 
The cost of sold goods sold and provided services includes the expenses of the main activity and the indirect costs of production.

The model of the profit and loss account with the classification of expenses by nature has the advantage that the financial analyst can study the consumption of inputs, by reporting various expenses classified by nature in the production of the exercise. In this way it can be establish the wealth created by the enterprise expressed through the added value and the way this wealth is distributed.

The added value expresses the growth of value that results from the use of production factors, especially labor and capital factors, over the amount of raw materials, the purchased materials and services from other enterprise, so the added value represents the wealth created by the enterprise by exploiting the technical, human and financial resources of other companies. This indicator expresses the contribution of the company in the production of goods and services, allowing the assessment of the degree of integration as a ratio between the added value and the turnover, and provides information about the progress or the regress of the company's activities.

In analysis, the added value is seen, primarily, as an indicator of performance, and secondly, as an indicator in the taxation system.

In a global economy, there is a financial conception, according to which the enterprise, in its capacity as a trader, fulfills a dual role, namely creates wealth expressed by the added value and contributes to the wealth distribution in the form of salaries, taxes interests, depreciations, results.

Meanwhile, the profit and loss account divided by the classification of expenses and incomes by their nature, presents particular interest for the government and its organs. They require information to regulate the enterprise activities, to determine the fiscal policy, but also to calculate the national product, the national income, and other similar indicators.

This model shows a number of features and compatibility between national accounts and enterprise accounts.

The model of profit and loss account as a list, built on the basis of classification of expenditures and revenues by their functions, has the advantage that it offers the financial analyst the opportunity to study the enterprise functions by reporting the various costs to the sold production, thereby underline the efficiency of the management.

This model of profit and loss account shows particular information interest for the equity investors. Those in the quality of bidders are interested in the risk of investment and the profits made by their investment. They need information to decide whether to buy, or keep, or sell. Also, shareholders are interested in information which would help them to assess the company's ability to pay dividends. All these information is provided mainly by the profit and loss account with the classification of the expenditures and revenues by function.

Currently, the models for profit and loss account shown above are used the most, both in vision of the international standard IAS 1, with the classification of expenses by nature and by their function, each model with its advantages and limitations, and in view of the European Accounting Directives which we considered important to analyze the list model with two approaches: the classification of expenses by nature and by function (destinations), also pointing out the advantages and limitations of each model.

\section{The Thacker model for the profit and loss account}

Another model for the profit and loss account which worth mentioning is that proposed by the economist RJ Thacker, taking into consideration the fact that in the accounting literature in Romania was very little written about this model.

RJ Thacker comes with a very interesting proposal for the classification of information in the profit and loss account, on fixed and variable elements, in terms of management efficiency. The author based his proposal on the idea that investors track and choose the management which ensures the maximization of the profit. The model for profit and loss account proposed by the 
economist RJ Thacker contains an initial classification of the items such as fixed / variable and a functional subset.

The Thacker model for the profit and loss account

\begin{tabular}{|l|}
\hline Net sales \\
Variable costs \\
Raw materials, wages and other production costs \\
Distribution expenses \\
Administrative expenses \\
Total \\
The operating net margin \\
Fixed costs \\
Production expenses \\
Distribution expenses \\
Administrative expenses \\
Total \\
The net result of the activity \\
Source: Nobes, Ch., Comparative International Accounting
\end{tabular}

Table no. 3

The benefits of the model:

- The separation of elements in fixed and variable makes it easier to determine and analyze the concept of earning power, which is a measure of performance;

- The model allows the presentation and calculation of a marginal indicator regarding the performance of the enterprise management;

The limits of the model:

- the difficulty in accurate separation of the expenses in fixed and variable, especially for the semi-variable ones.

\section{Conclusions}

We consider necessary to mention that, through the global convergence project on accounting level, was establish the normalization of financial statements that includes all the result elements, whether they are recognized in the period result or in other elements of equity, this way offering a more global imagine over the performance of the enterprise.

The financial, economical, legal and cultural particularities of every country influence the enterprise to choose the model of profit and loss account which best correspond to the informational requests of users. That is why, in view of the two accounting referential, the models of profit and loss account were correlated with the advantages and limits offered to the users.

The profit and loss account remains the most representative financial statement to measure the performance of the enterprise activity.

Moreover, in order to respond to every request regarding the global information on result, on the information over the nature and destination of the expenses, through the convergence project on accounting level, was establish an integrated situation over the performance enterprise by the specialists, a situation which offers a global image on the enterprise performance.

\section{References}

1. Bunget, O., 2005. Contabilitatea romaneasca intre reforma si convergenta, Economica Publishing House, Bucharest 
2. Colasse, B., 2009. Fundamentele contabilitatii, translation published by TipoMoldova Publishing House, Iasi.

3. Epstein, J., Mirza, A., 2002. Interpretation and application of International Accounting Standards, John Wiley Sons Inc.

4. Feleaga, N., Malciu, L., 2004. Recunoastere, evaluare, estimare in contabilitatea internationala, CECCAR Publishing House, Bucharest

5. Feleaga, N., Malciu, L., 2007. Contabilitatea financiara. O abordare europeana si internationala, editia a 2 a, Economica Publishing House, Bucharest

6. Horomnea, E., 2010. Fundamentele stiintifice ale contabilitatii, TipoMoldova Publishing House, Iasi.

7. Ionascu, I., 2003. Tendinte internationale privind (de)reglementarea contabilitatii firmelor. Invataminte pt.Romania, CECCAR Publishing House, Bucharest

8. Iacob, P. si Bodea, G., 2008. Contabilitate financiara romaneasca, Intelcredo Publishing House, Deva

9. IASB, 2009. Standardele Internationale de Raportare Financiara, CECCAR Publishing House, Bucharest

10. Jianu, I., 2007. Evaluarea, prezentarea si analiza performantei intreprinderii. O abordare prin prisma IFRSurilor, CECCAR Publishing House, Bucharest

11. Nobes, Ch., Parker, R., 2008. Comparative International Accounting, FT Prentice Hall.

12. Revsine L., Collins, D.W., Johnson, W.B., 2005. Financial Reporting and Analysis, third edition, Pearson Prentice Hall.

13. Ristea M., Dumitru, G., 2009. Contabilitatea societatilor comerciale, Vol.I si Vol.II, Universitara Publishing House, Bucharest 